\title{
Algorithms applied in decision-making for sustainable transport
}

\author{
Luciano Barcellos de Paula $^{\text {a, * }}$, Fernando Augusto Silva Marins ${ }^{b}$ \\ a CENTRUM Católica Graduate Business School, Pontifical Catholic University of Peru, Peru \\ ${ }^{\mathrm{b}}$ College of Engineering, Campus of Guaratingueta, Sao Paulo State University, Brazil
}

\section{A R T I C L E I N F O}

\section{Article history:}

Available online 5 December 2017

\section{Keywords:}

Urban transportation systems

Public value

Sustainability

Logic fuzzy

Stakeholder engagement

Decision-making

\begin{abstract}
A B S T R A C T
Global warming, as many other threats, requires more activity from the government, and people inquire about this, rightfully so. However, the public and private sectors nowadays have a joint responsibility with society. Global warming has come out of the scientific community and shows that climate change is an important social, economic, and political issue. Currently the carbon dioxide $\left(\mathrm{CO}_{2}\right)$ emissions by transportation sector are the main polluter of the planet. For this reason, in this paper we propose a reflection on transport, which is an important sector of the economy, responsible for the generation of many jobs and wealth but, at the same time, it has negative impacts on people, companies, and the environment. Recent investigations demonstrate that mobility problems affects the life quality of the people, business productivity and gross domestic product (GDP) performance. In the face of the changes that we are experiencing, it is important to find alternatives that assistance governments in the decisionmaking to solve the problem of traffic in large and medium-size cities and bring well-being to the population. The goal is to provide accurate tool to help take the best decisions in situations that most of the time has a lack of economic resources and transparency. Another motivation is to increase the productivity of companies and achieve sustainable development by reducing mobility problems and $\mathrm{CO}_{2}$ emissions. As outcomes of the paper, an in-depth study is presented on the subject that indicates a gap in the literature with fuzzy logic applied to sustainability. We indicate a sustainable option for the transport sector using algorithms for decision-making, and broaden the discussion on climate change and solutions to reduce the impacts caused by humanity. When the models were applied through a conceptual study, it was possible to provide an instrument generated on the use of algorithms that can aid decisionmaking by getting qualitative data from a discussion with stakeholders on a topic. Finally, the document identifies the importance of the participation of stakeholder, reinforces legitimacy and transparency in decision-making processes and above all present a tool that can help governments to solve this problem. In short, this work proposes an original and valuable tool to be applied in the decision-making process for the sustainable transport sector based on the stakeholder engagement.
\end{abstract}

() 2017 Elsevier Ltd. All rights reserved.

\section{Introduction}

According to "Brundtland Report" (WCED, 1987) the sustainable development must meet the current needs without compromising the future of the next generations. The need to promote sustainable economic development is a challenge for private companies (Baumgartner and Rauter, 2017; França et al., 2017) and for the public sector that, in recent decades, have sought alternatives through international pacts. On the other hand, we perceive the

\footnotetext{
* Corresponding author.

E-mail addresses: lbarcellosdepaula@pucp.edu.pe (L. Barcellos de Paula), fernando.marins@outlook.com (F.A.S. Marins).
}

development of certification systems and codes of conduct that lead enterprises to implement management tools for sustainable development.

The issue of global warming has come out of the scientific community (Broman and Robèrt, 2017; Rauter et al., 2017; Missimer et al., 2017) and shows that climate change is an important social, economic, and political issue. According to Mezouar (UNFCCC, 2017), climate action remains undeniable and irreversible, and the collective efforts to combat climate change do not stop. The same author emphasized the importance of joint action by several stakeholders and affirmed that state and non-state actors, governments, civil society, business, non-governmental organizations (NGOs) and universities are engaged in the transition to a clean and sustainable future with economic opportunities and jobs. 
The transport sector is responsible for the emissions of $\mathrm{CO}_{2}$ to a greater extent, since it is a greenhouse gas that pollutes and largely causes the earth's warming. It is generally considered polluting when it is associated with cars, airplanes, power plants and other human activities that require the use of fossil fuels, such as gasoline and natural gas.

Over the past 150 years, these activities have sent enough carbon dioxide into the atmosphere to raise carbon dioxide levels above where they had been for hundreds of thousands of years (National Geographic, 2010). In addition, as recently noted by Álvarez (2017), transportation is a problem that we see every day, and that generates a loss of wealth generation by cost of opportunities, and it is lost (men-hours) harming the productivity of companies.

Another research carried out in Rio de Janeiro by Vianna and Machado (2016), affirmed that the cost of time that could be invested in productivity reached $\mathrm{R} \$ 35.7$ billion in 2014. The amount corresponds to $8.1 \%$ of the region's gross domestic product (GDP). The same authors believe that time lost in people's way to work could be turned into income.

To obtain the numbers, the historical series of the National Household Survey (PNAD) of the Brazilian Institute of Geography and Statistics (IBGE) is used. The sample has compared the mean travel time data and the average working hour value of the employed population in each of the nine major metropolitan areas of the country.

In Brazil, the percentage of GDP lost (8.1\%) with changes in the metropolitan area of Rio de Janeiro exceeds the loss of Belem (6.6\%), Sao Paulo (6.2\%), Belo Horizonte (5.2\%), Salvador (5.2\%), Recife (4.6), Fortaleza (4.2\%), Porto Alegre (4\%) and Curitiba (4\%). Nationwide, Brazil loses more than $\mathrm{R} \$ 232$ billion, corresponding to $2.7 \%$ of its GDP, according to Vianna and Machado (2016).

In the United States of America, it is estimated to have lost approximately $\$ 160$ billion, mostly in metropolitan areas with traffic problems, which represented about 1 percent of the country's GDP. This percentage has remained constant over the last few years (Schrank et al., 2015).

For Vuchic (2008), the experiences from recent decades have shown that urban transportation is much more complex than what is usually realized. A sustainable city requires a public policy to efficiently coordinate various modes of transportation with vehicles and pedestrians. According to the same author, transportation is interrelated with other services and supply systems, such as energy, water, and environmental conditions; hence, all these systems are essential for the operation of cities and for their present liveability and projected sustainability.

On the other hand, Su et al. (2012) present an alternative for the transport sector with plug-in hybrid electric vehicles (PHEVs) and plug-in electric vehicles (PEVs). According to the authors, these technologies can offer greater energy efficiency, low carbon emissions, energy independence and environmental responsibility. The authors raise technical issues related to industrial information technologies in the future and highlight the need for Intelligent Energy Management to reduce costs on new generations, transmission and distribution, and present a framework to facilitate the integration of PHEVs/PEVs.

For Amini and Islam (2014) the electric vehicles (EVs) contribute more for the environment compared to other types of vehicles. The authors explain about the need for planning and optimization of electric vehicle parking in the distribution network through the application of algorithms.

Evaluate the transportation modals that will work for a city is a complex task due to the big ranges of features of the each kind transportation. It involves chose from a wide variety of characteristics which can have different weights given by a group of people charged of the decisions. That is why apply a mathematical model can be useful for have a more accurate and trustily answers, besides of a consensus among the stakeholders.

In this context, it is important that the stakeholder engagement is carried out very well so that this relationship can create value for cities in a sustainable manner. Because of this complexity, it is essential to address stakeholder management in an approach based on complex systems and models that help governments make decisions, especially in an uncertain environment. For these reasons, it is justified to analyse the sustainable management of government purchases using fuzzy logic algorithms from the dialogue with stakeholders.

In this work, we emphasis on the sustainable alternative for the transport sector using the algorithms of Fuzzy Logic, for example, the Adequacy Ratio, Hamming Distance, and Ordered Weighted Average (OWA) Operators, to discovery models that will support governments in making decisions with the application of this methodology.

Also, this paper aims to expand the discussion on climate change and solutions to reduce the impacts caused by humanity. A motivation is to find a sustainable transport alternative that can improve the quality of life of people, increase the productivity of companies, and achieve sustainable development.

To achieve these objectives, we adopted the applied research method, with a quantitative approach through modelling and simulation (Fig. 1).

As contributions of the document, an in-depth study is presented on the subject that indicates a gap in the literature with fuzzy logic applied to sustainability. It also indicates tools for decision-making considering sustainability criteria.

Furthermore we expect with this work to help face the existing challenges such as mobility problems, the impacts of the transport sector in cities, the reduction of $\mathrm{CO}_{2}$ emissions and the decisionmaking of governments to solve this problem.

Finally, the document identifies the importance of the participation of stakeholder, and reinforces legitimacy and transparency in decision-making processes. We consider that our input will serve to encourage further study on the use of algorithms to

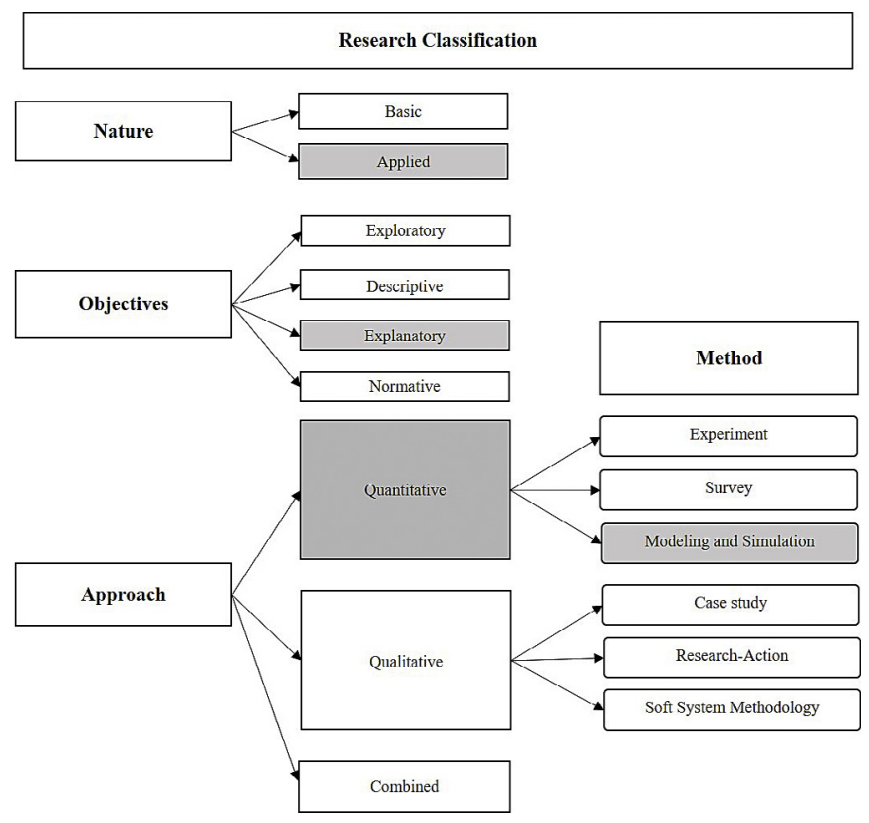

Fig. 1. Research classification (Adapted from Bertrand and Fransoo, 2002). 
sustainability, a field that can be further researched in depth. This paper is organized as follows:

- Section 2 presents a summary of the literature on transport and then present a sustainable alternative for the transport sector.

- Section 3 explains the models of fuzzy logic that can be used in the transport sector and, from a review of the literature on "fuzzy logic applied to sustainability", it identifies the existing research gaps and the most cited works.

- Section 4 applies three models of fuzzy logic to choose a more sustainable transport alternative and then, it shows the results.

- Section 5 presents the conclusions of the manuscript, the suggestions for its continuity, followed by the bibliographical references used.

\section{Aeromovel System - a sustainable alternative for the transport sector}

Kennedy et al. (2005) stated that for obtaining a sustainable transportation system four conditions should be satisfied: existence of a qualified structure for managing the land use and the transportation; availability of a fair and efficient financing system; strategic investments in infrastructure; and special care with neighbourhoods' projects.

According to Vasic et al. (2012), it soon became obvious that even an extensive network of metro lines could not meet the needs of all urban areas: although the subway provides faster and better service, its network does not have the density that modern cities require. For that reason, many cities developed several modes of rail system, i.e. tramway, light rail transit (LRT), subway, and regional railway (Babalik-Sutcliffe, 2002; Vuchic, 2005; Hensher, 2007; Thanh et al., 2008; Brons et al., 2009).

In this way, tramways continue to serve not only the existing but also the increased and modernized tramway network. The cities of Budapest, Munich, Prague, and Brussels modernized their trains. And other cities in Germany have developed networks that are a combination of LRT and tramway. (Topp, 1998; Griffin, 2002; Novales et al., 2002).

It should be noted that cities such as Paris, London, Hong Kong, and Madrid, which destroyed large transit networks during the period 1930-1960, are now constructing new transit lines (Novales et al., 2003; Ison and Rye, 2005; Vuchic, 2005; Pucher et al., 2007).

For Ferbrache (2017), there are positive effects when light rail is adopted; however, these impacts depend on the geographical location and they can vary over time. This indicates that some cities seek to maximize impacts through urban planning and integrated transportation strategies. According to the same author, these impacts include: a new and modern image, an own cultural identity, good reputation, social inclusion improvement, better environmental quality and adequate physical transformations.

In some places, a key objective of new light rail schemes has been improvement of environmental quality through noise and pollution reduction. However, Babalik-Sutcliffe (2002) points out that none of the eight new light rail systems in the United Kingdom, Canada and the United States have met their environmental objectives, suggesting that this proposal was not adequately agreed upon with stakeholders (Hass-Klau et al., 2004; Mackett and Edwards, 1998).

Evidence also exists in respect to the environmental performance of diverse transit systems: when compared with buses, light rail has been found to generate less noise and vibration, but is roughly equal in terms of $\mathrm{CO}_{2}$ and other emissions (Knowles, 1992; Hodgson et al., 2013). According to Lin and Omojub (2017), "the Asian countries with the largest investments in the transport sector and with private sector participation in recent years tend to have lower $\mathrm{CO}_{2}$ emission from the transport sector".

Vuchic (2008) believes that it is relevant for medium and large cities to adopt distinct transport modes, because they offer greater choice of travel, with better reliability, and safety. In general, these intermodal transport systems provide more solutions in terms of sustainability in contrast to unimodal systems, if they are well planned and implemented.

Vuchic (2008) also argues that the provision and coordination of different modes is, however, more complex than design and operation of a single mode. It involves different agencies, different methods of financing and payments. In addition, to a greater complexity, planning and implementation of intermodal systems requires greater professional expertise and, often, protection from special interest groups and lobbies. For Robèrt (2017), the planning of a strategic stakeholder-driven transport is still a field that should be further studied and developed.

In other hand, to create public value there must be a connection between policy design and public management. The public value should include the provision of services, achievement of social results and maintenance of trust and legitimacy.

The term "public value" (Mark Moore, 1995) that we use in this article refers to "the public sector equivalent of private value in corporate management". In this way, public managers seek to maximize the value to citizens of their activities.

The use of appropriate consultation and deliberation processes with stakeholders can promote convergence in perceptions of public value. Therefore, these processes increase the public value of the services provided and stakeholder engagement.

In order to seek proposals of public value, it is essential to listen carefully to the stakeholders, engage them, and use their expertise to guide the development of policies (Mintrom and Luetjens, 2017). In addition, public policies and programs must be developed through collective and collaborative processes that meet the needs of the population. It is valuable to study the linkages between policy and practice through the lens of public value (Alford \& O'Flynn, 2009; Bozeman, 2007, 2009; Moore, 1995, 2013; Moulton, 2009; Talbot, 2009).

\subsection{An overview about Aeromovel System}

An alternative to be studied by governments could be the use of the Aeromovel System, are shown in Figs. 2 and 3, which is a $100 \%$ automatic means of transport (there are no drivers on board). The Aeromovel is an automated means of transport in elevated way, composed by vehicles light and non-motorized.

The Aeromovel System has the technology of pneumatic propulsion. The system utilizes stationary high efficiency energy fans to boost the air through that duct located within the elevated track. The system allows air to push the propeller plate attached to the vehicle, which moves on a platform on steel wheels.

According to Coester (2017), the system works with very low production and maintenance costs and fits into the category called Automated Transit System (ATS), because it refers to fully automatic guided passenger transport systems exclusively. Therefore, the Aeromovel can be used for both mass urban transport and smaller systems. In Table 1, we include the main characteristics of the Aeromovel.

Finally, Coester (2017) explained that industrial ventilators are used for propulsion, and, in general, they are located on the top of the stations of passengers. There are pneumatic circuits to individually control each vehicle in order to provide a safe and intrinsic separation among the vehicles, and there is generator equipment to guarantee that interruptions in system operations be minimized. 


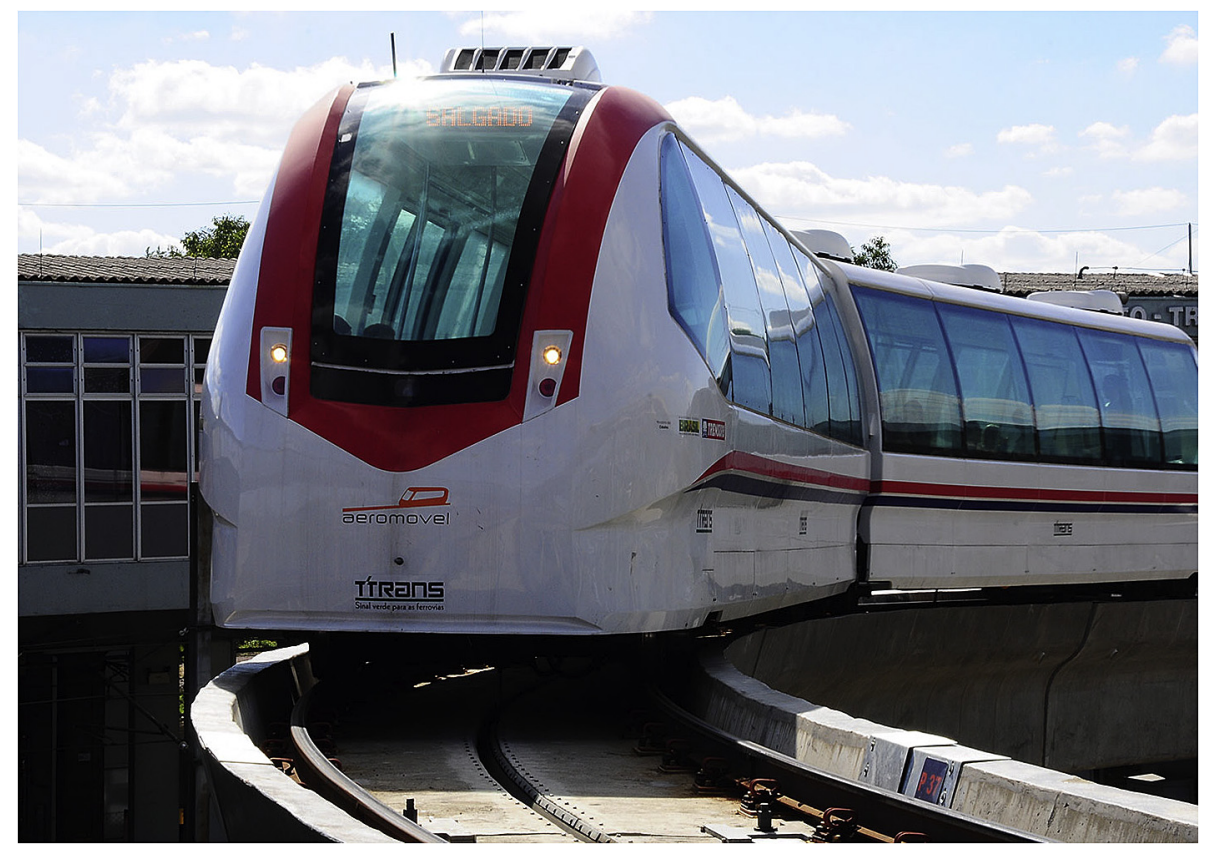

Fig. 2. The Aeromovel system in Porto Alegre, Brazil. Source: Coester (2017).

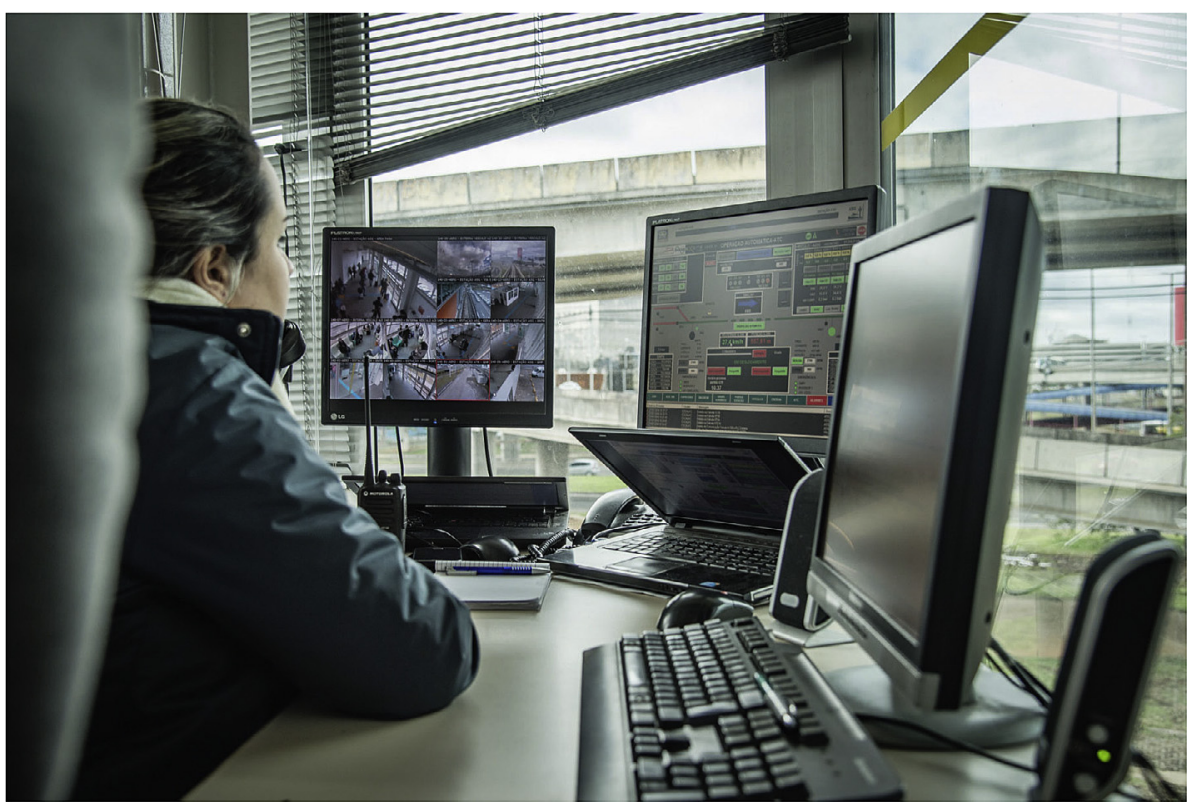

Fig. 3. The Aeromovel system in Porto Alegre, Brazil. Source: Coester (2017).

Table 1

Characteristics of the Aeromovel (Own source based on Coester, 2017).

\begin{tabular}{|c|c|c|c|}
\hline General features & Performance & Safety & Comfort \\
\hline $\begin{array}{l}\text { "Easy insertion and integration in the urban } \\
\text { environment". }\end{array}$ & $\begin{array}{l}\text { "It can carry up to } 40 \text { thousand passengers per } \\
\text { hour according to project". }\end{array}$ & $\begin{array}{l}\text { "There is no chance of collision } \\
\text { between vehicles". }\end{array}$ & $\begin{array}{l}\text { "It follows the international standard of } \\
\text { comfort". }\end{array}$ \\
\hline $\begin{array}{l}\text { "Low investment in implementation, and } \\
\text { small cost in operation and maintenance". }\end{array}$ & "Efficient insulation of noise and vibration". & "No electromagnetic impact". & $\begin{array}{l}\text { "World class - APM guided transport } \\
\text { system, fully operated on exclusive lanes". }\end{array}$ \\
\hline $\begin{array}{l}\text { "Low weight per passenger; Consumes little } \\
\text { energy". }\end{array}$ & "Acceleration up to $1.10 \mathrm{~m} / \mathrm{s}^{2}$ ". & $\begin{array}{l}\text { "Environment and } \\
\text { Sustainability; Redundant } \\
\text { control systems". }\end{array}$ & "Access for disabled". \\
\hline $\begin{array}{l}\text { "Fully automated line; Light vehicle that } \\
\text { works on rails. Clean technology". }\end{array}$ & $\begin{array}{l}\text { "Adjustable operating parameters by selecting } \\
\text { speed profiles and predefined feed rates". }\end{array}$ & $\begin{array}{l}\text { "Safe in the event of an } \\
\text { earthquake". }\end{array}$ & "Silent vehicles without engine noise". \\
\hline "It conforms to international standards". & "Speed up to $80 \mathrm{~km} / \mathrm{h}$ ". & $\begin{array}{l}\text { "The system works even with } \\
\text { power interruptions". }\end{array}$ & "Facilitated access to the stations". \\
\hline
\end{tabular}




\subsection{The Aeromovel System success stories and future projects}

The first Aeromovel project was implemented in 1989 in Jakarta, Indonesia, inside an ecological park. As shown in Fig. 4, this line is $3.6 \mathrm{~km}$ long, includes six stations, and it has operated very well until now (Coester, 2017).

In 2013 the Aeromovel was installed in Porto Alegre, shown in Fig. 5. The project connects the Airport Station of the subway to Terminal 1 of Airport.

Another Aeromovel project is under construction in the city of Canoas, Brazil, and will have $18 \mathrm{~km}$ and 27 stations. Other cities such as Los Angeles, USA, Rio Negro (see in Fig. 6) and Medellin, Colombia, Johannesburg, South Africa, Berlin, Germany, and countries like Panama and Argentina have advanced studies on the implementation of this means of transport. The Aeromovel System respects the environment and solves the problem of displacement in large and medium cities.

In this section, it presented a reflection on the challenges on sustainable transportation from a literature review and indicated a sustainable alternative for the sector. Following, it will explain three methodologies that can be used in decision making in the transport sector, and that will be applied in this article.

\section{Material and methods}

This section describes the three algorithms that can be applied in decision making to choose the best option in sustainable transport for a city, and that will be used in this article. From the literature review on "fuzzy logic applied to sustainability", the existing research gaps and the most cited works will be identified. However first it presents a brief introduction to Fuzzy Logic.

The Fuzzy-Logic constitutes a mathematical theory in the field of multivalent logics. Its origin is in the works that realized by Lofti Zadeh (1965). Zadeh put the term "fuzzy" to multivalent sets, whose elements belong to them in different degrees to mark the difference between that concept and the then universally accepted binary logic. At the same time, Kaufmann (1973) was working on a book that would later be the first to be published in the field of fuzzy mathematics.

At first, the Fuzzy-Logic has been applied in the field of Formal Sciences, but in the last 45 years, researchers (Yager, 1993; Pedrycz, 1994; Gil-Lafuente, 2001; Xu Zs, 2007) from all over the world have published many papers and studies with applications to different fields.

For Blanco-Mesa et al. (2016) the use of fuzzy logic helps the decision maker in uncertain environments since he can evaluate the information available through fuzzy sets and systems.

To deepen the analysis of the literature, a bibliometric study was performed and the results show that the application of the fuzzy logic to the sustainability has been little researched until the moment. Fig. 7 shows the results of publications (only twelve papers) and citations (one hundred and seventy and two references) obtained through the Web of Science by using the keywords "Fuzzy logic applied in sustainability", and so, it was evidenced that there is an opportunity to explore innovative research in this area.

Table 2 presents the most cited works using the keywords "fuzzy logic applied to sustainability", their contributions and research gaps.

The results of the bibliometric study identified the research gaps using algorithms of the fuzzy logic applied to sustainability. It was evidenced that there is an opportunity to explore more involving innovative research in this area.

In this work, we use some concepts that are described in the sequence.

(a) Hamming Distance (Kaufmann and Gil Aluja, 1987)

Definition 1. "Firstly, we define a notion of distance between two points included in the segment

$$
\begin{aligned}
{[0,1] } & : \text { If }\left[a_{1}, a_{2}\right] \subset[0,1] \text { and }\left[b_{1}, b_{2}\right] \subset[0,1], \text { let } \mathrm{D}\left(\left[a_{1}, a_{2}\right],\left[b_{1}, b_{2}\right]\right) \\
& =\frac{1}{2}\left(\left|a_{1}-b_{1}\right|+\left|a_{2}-b_{2}\right|\right)
\end{aligned}
$$

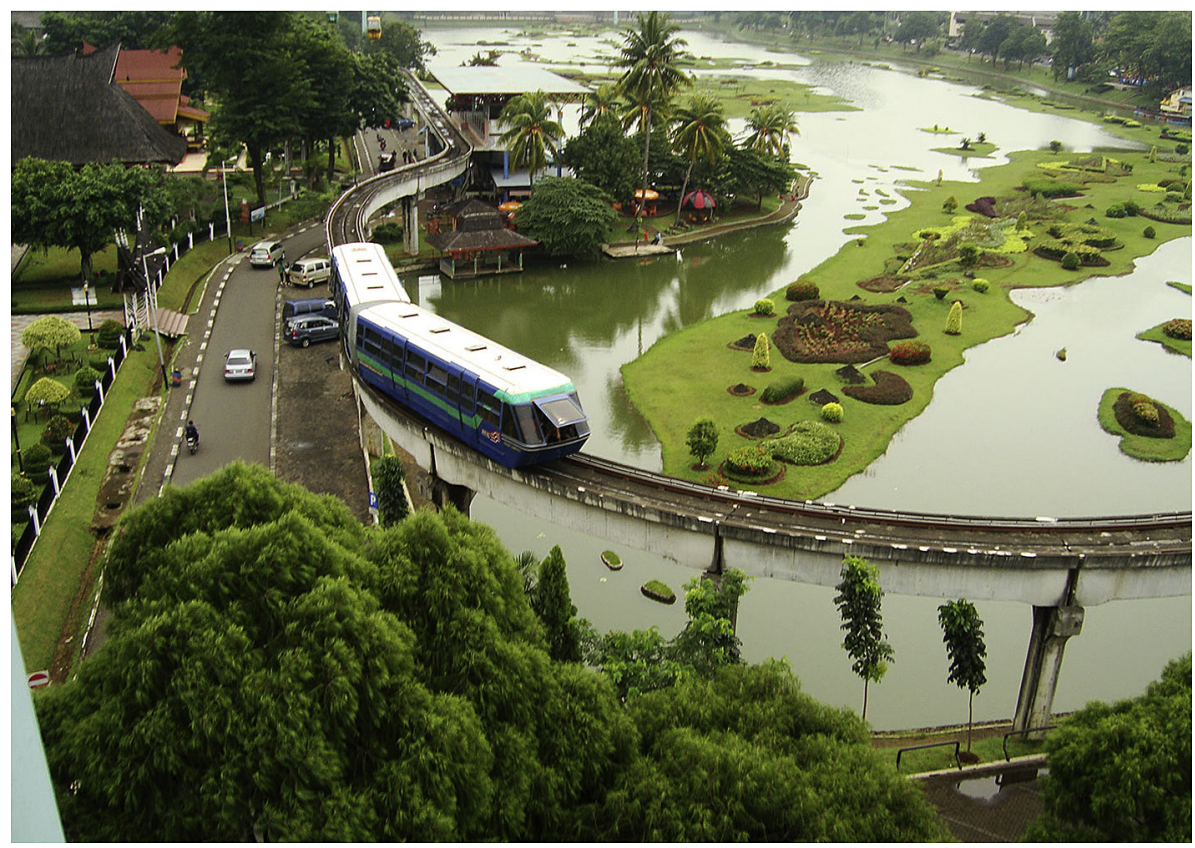

Fig. 4. The Aeromovel system in Jakarta, Indonesia. Source: Coester (2017). 


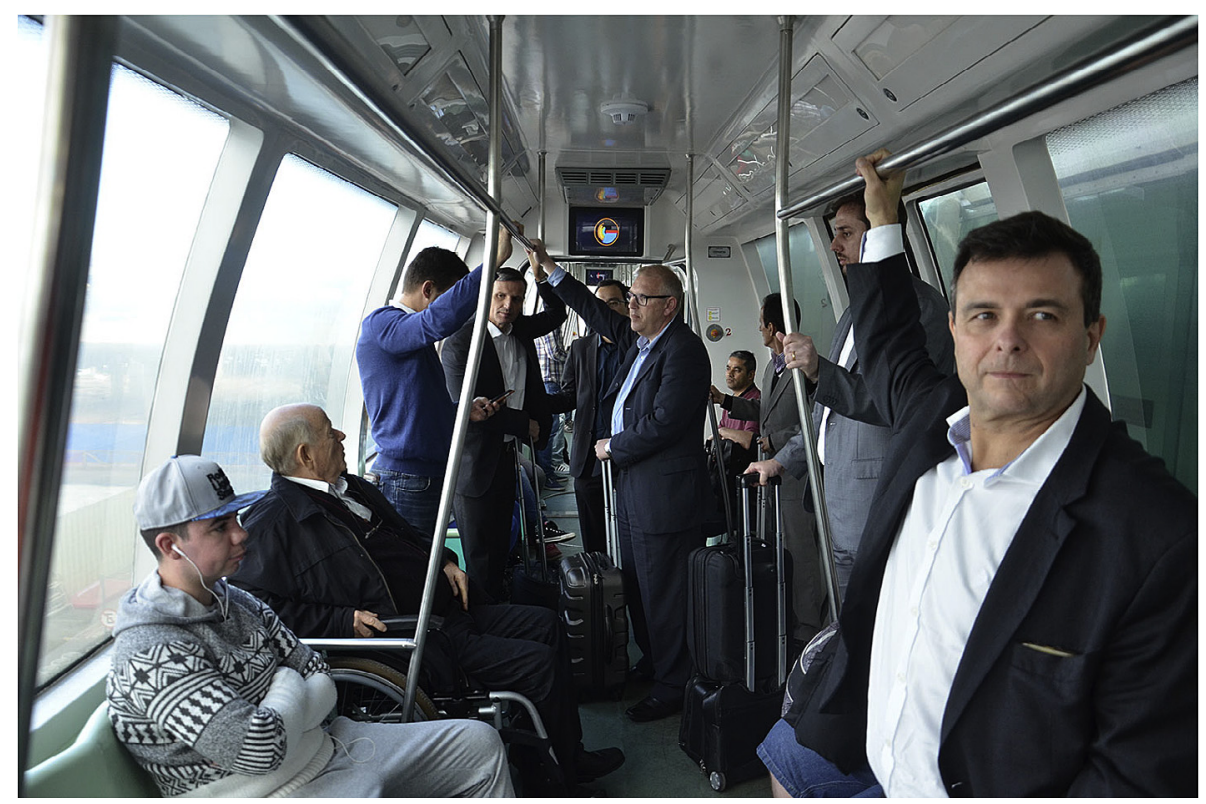

Fig. 5. The Aeromovel system in Porto Alegre, Brazil. Source: Coester (2017).

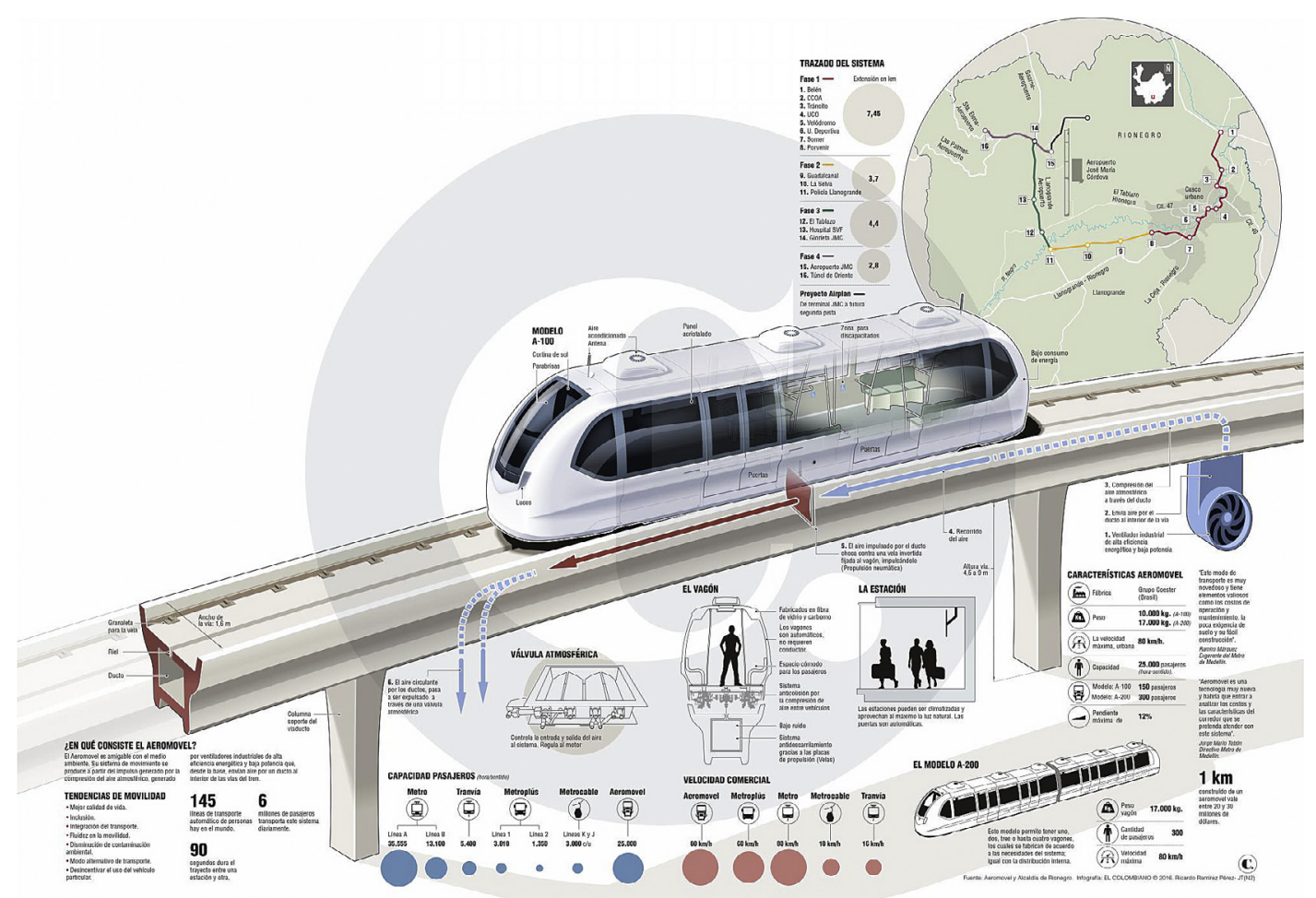

Fig. 6. The Aeromovel Project in Rio Negro, Colombia. Source: Aeromovel and mayor of RioNegro. Infographic: the Colombian (2016), Ricardo Ramírez Pérez - JT (N2).

that define an object or proposal $a_{j}, j=1,2, . ., m$, through certain characteristics or elements $b_{i}, i=1,2, . ., n$

The use of $\frac{1}{2}$ before the addition of absolute values is intended only to maintain the distance between 0 and 1 . As a result, we observe that

$0 \leq \mathcal{D}\left(\left[a_{1}, a_{2}\right],\left[b_{1}, b_{2}\right]\right) \leq 1$
Definition 2. We can define the normalised Hamming distance between two subsets $\Phi$ - the same reference fuzzy finite:If $\underset{\sim}{A}, \stackrel{B}{\sim} \subset E$ with a card $E=N$ finite, we have

$\delta\left(\begin{array}{cc}A & B \\ \sim & \sim\end{array}\right)=\frac{1}{n} \sum_{i=1}^{N} \mathcal{D}\left(\mu_{\sim}^{a}(x), \mu_{\sim}^{b}(x)\right)$ 

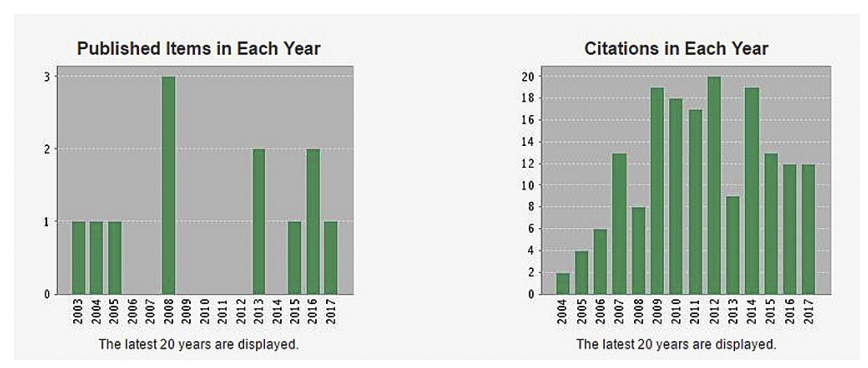

Fig. 7. Bibliometric study by searching the keywords "Fuzzy logic applied in sustainability". Source: Web of Science (2017).

where $\mu$ is the associated weighting vector".

"The Hamming distance has provided very good results when ordering fuzzy sets, since we will determine which item is "closer" to the ideal. The model, if we give more weight to some characteristics or skills than to others, allows us to consider and pursue the same expression quoted above. For all cases, one should prefer the element that is the smallest distance from what is considered the ideal" (Kaufmann and Gil Aluja, 1987).

(b) The Adequacy Ratio (Gil Aluja, 1999)

“Taking different variants, we chose the assumption penalty for those elements in which their characteristics do not reach the minimum. This penalty is applied gradually, in proportion to the deficit that exists" (Gil Aluja, 1999).

"We are going to initiate the process from the knowledge of certain fuzzy sub-relations that define an object or proposal $P_{j}$ $, j=1,2, . ., m$ through certain characteristics or elements $C_{i}$ $, i=1,2, . ., n$ and $\mu$ is the ideal level that is demanded.

The adequacy ratio is designated by $K\left(\begin{array}{cc}P_{j} & P^{*} \\ \sim & \sim\end{array}\right)$ and is constructed as follows:"

$$
\begin{aligned}
& \text { when } \mu_{\sim}^{P_{j}}\left(C_{i}\right) \geq \mu \stackrel{P_{*}}{\sim}\left(C_{i}\right) \text { do } K_{i}\left(\underset{P_{j}}{\sim} \underset{\sim}{\sim}\right)=1 \\
& \text { and when } \mu \underset{\sim}{P_{j}}\left(C_{i}\right)<\mu \stackrel{P_{*}}{\sim}\left(C_{i}\right) \text { do } K_{i}\left(\stackrel{P_{j}}{\sim} \underset{\sim}{\sim}\right) \\
& =1-\mu \stackrel{P *}{\sim}\left(C_{i}\right)+\mu \stackrel{P_{j}}{\sim}\left(C_{i}\right) \\
& \text { Then, } K\left(\begin{array}{c}
P_{j} \\
\sim
\end{array} \begin{array}{c}
P_{*} \\
\sim
\end{array}\right)=\frac{1}{n} \sum_{i=1}^{n} K_{i}\left(\begin{array}{c}
P_{j} \\
\sim
\end{array} \stackrel{P_{*}}{\sim}\right)
\end{aligned}
$$

\begin{tabular}{|c|c|c|c|c|c|}
\hline $\mathrm{N}^{\circ}$ & Authors & Paper & Method & Contributions & Gaps/suggestions for future research \\
\hline 1 & $\begin{array}{l}\text { Andriantiatsaholiniaina } \\
\text { et al. (2004) }\end{array}$ & $\begin{array}{l}\text { "Evaluating strategies for } \\
\text { sustainable development: fuzzy } \\
\text { logic reasoning and sensitivity } \\
\text { analysis" }\end{array}$ & $\begin{array}{l}\text { Modelling } \\
\text { and } \\
\text { simulation }\end{array}$ & $\begin{array}{l}\text { The authors "perform sensitivity analysis of } \\
\text { the Sustainability Assessment by Fuzzy } \\
\text { Evaluation (SAFE) model to identify the most } \\
\text { important factors contributing to sustainable } \\
\text { development". }\end{array}$ & $\begin{array}{l}\text { "The conclusion is that there is no unique } \\
\text { sustainable path and, accordingly, policy } \\
\text { makers should choose different criteria and } \\
\text { strategies to make efficient sustainable } \\
\text { decisions for each country". }\end{array}$ \\
\hline 2 & Prato (2005) & $\begin{array}{l}\text { "A fuzzy logic approach for } \\
\text { evaluating ecosystem } \\
\text { sustainability" }\end{array}$ & $\begin{array}{l}\text { Modelling } \\
\text { and } \\
\text { simulation }\end{array}$ & $\begin{array}{l}\text { "An alternative approach for evaluating strong } \\
\text { sustainability is proposed that uses fuzzy sets } \\
\text { to develop fuzzy propositions about } \\
\text { ecosystem attributes and strong } \\
\text { sustainability, and applies fuzzy logic to } \\
\text { evaluate those propositions". }\end{array}$ & $\begin{array}{l}\text { "An ecosystem manager needs to weigh the } \\
\text { advantages of a fuzzy logic approach in terms } \\
\text { of overcoming the limitation of conventional } \\
\text { approaches against the disadvantage of } \\
\text { greater informational requirements". }\end{array}$ \\
\hline 3 & Reynolds et al. (2003) & $\begin{array}{l}\text { "The science/policy interface in } \\
\text { logic-based evaluation of forest } \\
\text { ecosystem sustainability" }\end{array}$ & $\begin{array}{l}\text { Modelling } \\
\text { and } \\
\text { simulation }\end{array}$ & $\begin{array}{l}\text { The authors describe a logic-based "system for } \\
\text { evaluating the sustainability of forests at } \\
\text { regional and national levels". }\end{array}$ & $\begin{array}{l}\text { "A systematic way to organize expert } \\
\text { judgment about ecological, economic, social } \\
\text { and institutional relationships is crucial to } \\
\text { building such a system". }\end{array}$ \\
\hline 4 & $\begin{array}{l}\text { Kouloumpis et al. } \\
\text { (2008) }\end{array}$ & $\begin{array}{l}\text { "Sustainability Assessment of } \\
\text { Nations and Related Decision } \\
\text { Making Using Fuzzy Logic" }\end{array}$ & $\begin{array}{l}\text { Modelling } \\
\text { and } \\
\text { simulation }\end{array}$ & $\begin{array}{l}\text { The authors refined the "Sustainability } \\
\text { Assessment by Fuzzy Evaluation (SAFE) model } \\
\text { uses the so-called Takagi-Sugeno-Kang } \\
\text { inference scheme (TSK) which together with a } \\
\text { few technical requirements guarantees } \\
\text { monotonicity". }\end{array}$ & $\begin{array}{l}\text { "The model is applied to all countries of the } \\
\text { world for which data could be obtained and } \\
\text { their corresponding sustainabilities are } \\
\text { computed". }\end{array}$ \\
\hline 5 & Humphries (2008) & $\begin{array}{l}\text { "Suitability for conservation as a } \\
\text { criterion in regional conservation } \\
\text { network selection" }\end{array}$ & Case study & $\begin{array}{l}\text { The authors "developed an explicit rating of } \\
\text { conservation suitability by applying fuzzy- } \\
\text { logic functions in a knowledge base to } \\
\text { ecological condition and socio-economic } \\
\text { attributes of land units in the interior } \\
\text { Columbia River basin, USA". }\end{array}$ & $\begin{array}{l}\text { "The trade-off between suitability and } \\
\text { effectiveness in representing targets suggests } \\
\text { that a multi-stage process should be } \\
\text { implemented to address both attributes of } \\
\text { candidate conservation networks". }\end{array}$ \\
\hline 6 & Nie et al. (2016) & $\begin{array}{l}\text { "Planning renewable energy in } \\
\text { electric power system for } \\
\text { sustainable development under } \\
\text { uncertainty - A case study of } \\
\text { Beijing" }\end{array}$ & Case study & $\begin{array}{l}\text { "The interval type- } 2 \text { fuzzy fractional } \\
\text { programming (IT2FFP) method can help } \\
\text { decision makers identify desired alternatives } \\
\text { for managing such a mixed energy system in } \\
\text { association with sustainable development". }\end{array}$ & $\begin{array}{l}\text { "It is proved that IT2FFP is advantageous in } \\
\text { balancing conflicting objectives and reflecting } \\
\text { complicated relationships among multiple } \\
\text { system factors". }\end{array}$ \\
\hline 7 & Prato (2008) & $\begin{array}{l}\text { "Stochastic multiple attribute } \\
\text { evaluation of land use policies" }\end{array}$ & $\begin{array}{l}\text { Modelling } \\
\text { and } \\
\text { simulation }\end{array}$ & $\begin{array}{l}\text { "The stochastic MAE method can be used to } \\
\text { rank any set of management actions". }\end{array}$ & $\begin{array}{l}\text { "Use of the method can be simplified by } \\
\text { incorporating the various techniques and } \\
\text { parameters into a spatial decision support } \\
\text { tool". }\end{array}$ \\
\hline 8 & $\begin{array}{l}\text { Gil-Lafuente and Paula } \\
\text { (2013) }\end{array}$ & $\begin{array}{l}\text { "Algorithm applied in the } \\
\text { identification of stakeholders" }\end{array}$ & $\begin{array}{l}\text { Modelling } \\
\text { and } \\
\text { simulation }\end{array}$ & $\begin{array}{l}\text { "The application of algorithms in the } \\
\text { identification of stakeholders, and providing a } \\
\text { useful model in making decisions". }\end{array}$ & $\begin{array}{l}\text { "The article serves to support future research } \\
\text { in the field of application of algorithms to } \\
\text { business sustainability, environmental } \\
\text { management and economics". }\end{array}$ \\
\hline
\end{tabular}

(c) The OWA Operators (Yager, 1998)

Table 2

The most cited works using the keywords "fuzzy logic applied to sustainability" (Own source based on Web of Science, 2017). 
Table 3

Specific characteristics and proposals (Source: adapted from Vuchic, 2007, 2008, and Coester, 2007).

\begin{tabular}{|c|c|c|c|c|}
\hline & $\begin{array}{l}\text { Specific } \\
\text { characteristics }\end{array}$ & $P_{1}$ & $P_{2}$ & $P_{3}$ \\
\hline$C_{1}$ & Safety & $\begin{array}{l}\text { It is safe, but there is a chance of an accident } \\
\text { between vehicles. }\end{array}$ & $\begin{array}{l}\text { "In compliance to the standards of earthquake. No } \\
\text { chances of crash between vehicles due to air } \\
\text { compression inside the propulsion duct". }\end{array}$ & $\begin{array}{l}\text { It's safe but there is a chance of an accident } \\
\text { between vehicles, cars, bus, bicycle and } \\
\text { pedestrian. }\end{array}$ \\
\hline$C_{2}$ & $\begin{array}{l}\text { Energy } \\
\text { consumption }\end{array}$ & $86.118(\mathrm{Wh} /$ Passenger.Km) in peak hours. & $38.4(\mathrm{Wh} /$ Passenger.Km) in peak hours. & $69.45(\mathrm{Wh} /$ Passenger.Km) in peak hours. \\
\hline$C_{3}$ & $\begin{array}{l}\text { Environment } \\
\text { and } \\
\text { Sustainability }\end{array}$ & $\begin{array}{l}\text { Provides the highest land and energy } \\
\text { utilization. May cause negative impacts due } \\
\text { to water courses, archaeological sites. }\end{array}$ & $\begin{array}{l}\text { Clean technology. Minimum ground occupation. } \\
\text { "Compact stations, easily integrated to the } \\
\text { environment". }\end{array}$ & $\begin{array}{l}\text { Extremely environmentally friendly: quiet, } \\
\text { without exhaust, LRT vehicles traveling through } \\
\text { pedestrian areas add liveability to cities. }\end{array}$ \\
\hline$C_{4}$ & Comfort & $\begin{array}{l}\text { It's comfortable but in rush hour there can be } \\
\text { agglomeration of people. }\end{array}$ & $\begin{array}{l}\text { It's very comfortable. "Excellent sight for the } \\
\text { passengers during the journey. Silent vehicles with } \\
\text { no engine noise". }\end{array}$ & $\begin{array}{l}\text { It's comfortable. Excellent sight for the } \\
\text { passengers during the journey. }\end{array}$ \\
\hline$C_{5}$ & $\begin{array}{l}\text { Passenger } \\
\text { capacity }\end{array}$ & $\begin{array}{l}\text { Provides the highest capacity and for high } \\
\text { passenger volumes. } 80.000 \text { passenger per } \\
\text { hour. }\end{array}$ & $\begin{array}{l}\text { "Enabled to carry up to } 40 \text { thousands passengers } \\
\text { per hour". }\end{array}$ & Each car has the capacity to carry 420 people \\
\hline$C_{6}$ & $\begin{array}{l}\text { Maximum } \\
\text { speed }\end{array}$ & Speed up to $80 \mathrm{~km} / \mathrm{h}$ & Speed up to $80 \mathrm{~km} / \mathrm{h}$ & Speed up to $50 \mathrm{~km} / \mathrm{h}$ \\
\hline$C_{7}$ & Investments & Requires very large investment. & Low investment. & $\begin{array}{l}\text { Requires considerable investment, but lower } \\
\text { operating costs than buses. Lower investment } \\
\text { costs than metro. }\end{array}$ \\
\hline$C_{8}$ & $\begin{array}{l}\text { Incorporation } \\
\text { to the urban } \\
\text { location }\end{array}$ & Complicated & $\begin{array}{l}\text { The low rate of expropriation, due to its flexibility, } \\
\text { is one of the advantages of its design. }\end{array}$ & Complicated \\
\hline$C_{9}$ & $\begin{array}{l}\text { Dead weight } \\
\text { per passenger }\end{array}$ & $330 \mathrm{Kg}$ (150 pounds)/240 Passenger & $\begin{array}{l}\text { Very low dead weight per Passenger. } 110 \mathrm{Kg} \text { ( } 50 \\
\text { pounds)/300 Passenger }\end{array}$ & $330 \mathrm{Kg}$ (150 pounds)/240 Passenger \\
\hline$C_{10}$ & $\begin{array}{l}\text { Deadline for } \\
\text { implementation }\end{array}$ & High & Low & Medium \\
\hline
\end{tabular}

"An OWA operator of dimension $n$ is an application of $F: R^{n} \rightarrow R$, which has an associated weighting vector" (Yager, 1988), such as:

$w_{i} \in[0,1], 1 \leq i \leq n$ and $\sum_{i=1}^{n} w_{i}=w_{1}+w_{2}+\ldots,+w_{n}=1$

where $\mathcal{F}\left(x_{1}, x_{2}, \ldots, x_{n}\right)=\sum_{k=1}^{n} w_{k} x_{j k}=w_{1} x_{1}+w_{2} x_{2}+\ldots,+w_{n} x_{n}$

and $x_{j k}$ is the $k^{\text {th }}$ largest element of the collection $\left\{x_{1}, x_{2}, \ldots, x_{n}\right\}$.

Yager (1988) "introduced the so-called OWA aggregation operators, generalizing a model that only uses four decision criteria: Criterion optimistic, Criterion pessimistic or Wald Criterion, Hurwicz Criterion and Laplace Criterion" (Paula, 2011).

"A key aspect of the OWA operators is the reordering weigh. An aggregate $x_{i}$ is not associated with a weight, but weight is associated with an ordered position $j$ of the arguments. This arrangement introduces nonlinearity in the aggregation process" (Paula, 2011).

"The OWA operators provide great flexibility in being able to model a wide variety of aggregators, as their nature is defined by a vector of weights and not by a single parameter. Moreover, these operators allow trade-offs between conflicting objectives so that the development of a model is no longer feasible" (Paula, 2011).

"The advantages of this procedure are:

- It facilitates decision-making in conditions of a changing environment, conflict and uncertainty.

- It allows the interaction of various stakeholders in finding a consensus among one another on a specific topic.

- It assists in the analysis of complex systems, such as human resource management, by considering sustainability criteria.

- It provides flexibility to model various scenarios of ongoing business, among others" (Paula, 2011).
"The important constraint of the methodology is given mainly by the quality of the information collected. It is important that the entire process (approach, implementation and data processing) be conducted by a specialist in the subject under investigation and that the information collected is obtained from experts on the subject" (Paula, 2011). The application of the three models described above will be performed.

\section{Proposed methodology and results}

This section shows the result of applying three models of fuzzy logic to choose a more sustainable transport alternative. First, the Hamming Distance will be used; then, the Adequacy Ratio will be applied and, finally, the OWA Operators. The results will be subsequently shown.

"The approach that follows is based on the consideration of factors, estimates and data emerging from a real government demand and the results may allow a deep reflection and an application to academic and professional fields. It assumed that public administration decides to improve transport system" (Paula, 2011).

The main objective is to provide the population a sustainable alternative for the transport sector. The Purchasing Director typically decides to make these changes following a dialogue with the government's stakeholders.

According to Moore (1995), in general, the main stakeholders involved with the authorizing process are political leaders, senior public managers, and important groups as professional associations, unions, and business lobbies, among others.

The procedure includes, first of all, the government states the specific characteristics of the proposal, and second, based on the characteristics, are specify the proposals listed in Table 3, where $P_{1}$ to use Subway, $P_{2}$ to use The Aeromovel System, and $P_{3}$ to use Tramway and Light Rail Transit (LRT).

In cooperation with industry specialists, the fuzzy subset of thresholds was defined, denoted by ${ }_{\sim}^{P_{*}}$, which indicates the degree of significance of each feature, as shown in Table 4. 
Table 4

Fuzzy Subset of Thresholds (Own source, 2017).

\begin{tabular}{lllllllllll}
\hline & $C_{1}$ & $C_{2}$ & $C_{3}$ & $C_{4}$ & $C_{5}$ & $C_{6}$ & $C_{7}$ & $C_{8}$ & $C_{9}$ & $C_{10}$ \\
\hline $\begin{array}{c}P_{*} \\
\sim\end{array}$ & 0.9 & 0.9 & 0.9 & 0.9 & 0.75 & 0.8 & 1 & 0.9 & 0.8 & 0.9 \\
\hline
\end{tabular}

Table 5

Evaluation of three proposals (Own source, 2017).

\begin{tabular}{llll}
\hline & $P_{1}$ & $P_{2}$ & $P_{3}$ \\
\hline$C_{1}$ & 0.7 & 0.9 & 0.8 \\
$C_{2}$ & 0.8 & 1 & 0.8 \\
$C_{3}$ & 0.7 & 1 & 0.8 \\
$C_{4}$ & 0.8 & 0.9 & 0.8 \\
$C_{5}$ & 1 & 0.8 & 0.7 \\
$C_{6}$ & 0.9 & 0.9 & 0.8 \\
$C_{7}$ & 0.6 & 1 & 0.9 \\
$C_{8}$ & 0.6 & 0.9 & 0.8 \\
$C_{9}$ & 0.7 & 0.9 & 0.8 \\
$C_{10}$ & 0.8 & 0.9 & 0.9 \\
\hline
\end{tabular}

Table 6

Fuzzy Subset for each proposal (Own source, 2017).

\begin{tabular}{lllllllllll}
\hline & $C_{1}$ & $C_{2}$ & $C_{3}$ & $C_{4}$ & $C_{5}$ & $C_{6}$ & $C_{7}$ & $C_{8}$ & $C_{9}$ & $C_{10}$ \\
\hline$P_{1}$ & 0.7 & 0.8 & 0.7 & 0.8 & 1 & 0.9 & 0.6 & 0.6 & 0.7 & 0.8 \\
$P_{2}$ & 0.9 & 1 & 1 & 0.9 & 0.8 & 0.9 & 1 & 0.9 & 0.9 & 0.9 \\
$P_{3}$ & 0.8 & 0.8 & 0.8 & 0.8 & 0.7 & 0.8 & 0.9 & 0.8 & 0.8 & 0.9 \\
\hline
\end{tabular}

When the proposals and their features are submitted to the stakeholder representatives, it ask the specialists to specify their perceptions of the scale $[0,1]$, whereby the closer the estimate is to 1 , the better the adaptation to the requirements of city (Table 5 ). The items suggested are:

"This result allows us to obtain a fuzzy subset for each proposal" (Paula, 2011), as presented in Table 6.

"It will show the results of each proposal based on its own merits with respect to the initial proposal according to a set of thresholds. To achieve this goal, it will calculate the hamming distance" (Paula, 2011). In this case, it assume that the government determines a vector of weights (Table 7), depending on current priorities at any given time:

From (3), we obtain:

$$
\begin{aligned}
P_{1}= & \frac{1}{10}(0.05 * 0.2+0.25 * 0.1+0.3 * 0.2+0.05 * 0.1+0.01 * 0.25 \\
& +0.05 * 0.1+0.1 * 0.4+0.1 * 0.3+0.04 * 0.1+0.05 * 0.1) \\
= & 0.0187
\end{aligned}
$$

$$
\begin{aligned}
P_{2}= & \frac{1}{10}(0.05 * 0+0.25 * 0.1+0.3 * 0.1+0.05 * 0+0.01 * 0.05 \\
& +0.05 * 0.1+0.1 * 0+0.1 * 0+0.04 * 0.1+0.05 * 0) \\
= & 0.0065
\end{aligned}
$$

\begin{tabular}{|c|c|c|c|c|c|c|c|c|c|c|}
\hline & $C_{1}$ & $C_{2}$ & $C_{3}$ & $C_{4}$ & $C_{5}$ & $C_{6}$ & $C_{7}$ & $C_{8}$ & $C_{9}$ & $C_{10}$ \\
\hline$w=$ & 0.05 & 0.25 & 0.3 & 0.05 & 0.01 & 0.05 & 0.1 & 0.1 & 0.04 & 0.05 \\
\hline
\end{tabular}$$
P_{3}=\frac{1}{10}(0.05 * 0.1+0.25 * 0.1+0.3 * 0.1+0.05 * 0.1+0.01 * 0.05
$$$$
+0.05 * 0+0.1 * 0.1+0.1 * 0.1+0.04 * 0+0.05 * 0
$$$$
=0.0086
$$

Table 7

Vector of determined weights (Own source, 2017).
"With this result, the proposal with the shortest distance was selected, as it is conceptually closer to the subset of thresholds" (Paula, 2011). In this case, $P_{2}$ was selected, which is the Aeromovel System proposal. Then, we proceeded with the resolve of the same method, but this time it was built upon the technique based on the calculation of adequacy ratios. To do this, the relative distances between the subset of thresholds and each of the three proposals were found. From (6) it obtain:

$$
\begin{aligned}
K\left(P_{1} \rightarrow \begin{array}{c}
P_{*} \\
\sim
\end{array}\right) & =\frac{1}{10}(0+0+0+0+1+1+0+0+0+0.9) \\
& =0.290 \\
K\left(P_{2} \rightarrow \begin{array}{c}
P_{*} \\
\sim
\end{array}\right) & =\frac{1}{10}(1+1+1+1+1+1+1+1+1+1) \\
& =1.000 \\
K\left(P_{3} \rightarrow \begin{array}{c}
P_{*} \\
\sim
\end{array}\right) & =\frac{1}{10}(0+0+0+0+0+1+0+0+1+1) \\
& =0.300
\end{aligned}
$$

In this example, we select the $P_{2}$ proposal as the result with the highest adequacy ratio among the subset of thresholds and the proposal made by the Aeromovel System. This means that $P_{2}$ is the best proposal: "the values of the characteristic function of membership of each of its elements have a smaller total distance with respect to the subset threshold" (Paula, 2011).

Another technique for making decisions is founded on the models for the calculation of "the OWA operators" (Yager, 1988). "To calculate the OWA operators, the associated weighting vector (Table 8) is applied" (Paula, 2011).

\begin{tabular}{|c|c|c|c|c|c|c|c|c|c|c|}
\hline & $C_{1}$ & $C_{2}$ & $C_{3}$ & $C_{4}$ & $C_{5}$ & $C_{6}$ & $C_{7}$ & $C_{8}$ & $C_{9}$ & $C_{10}$ \\
\hline$w=$ & 0.05 & 0.25 & 0.3 & 0.05 & 0.01 & 0.05 & 0.1 & 0.1 & 0.04 & 0.05 \\
\hline
\end{tabular}

In Table 9 the data are reordered.

From (8), we can calculate $O W A P_{i}$, for $i=1,2$, and 3 , and the results are summarized in Table 10:

$$
\begin{aligned}
\text { OWAP }_{1}= & (0.05 * 1+0.25 * 0.09+0.3 * 0.8+0.05 * 0.8+0.01 * 0.8 \\
& +0.05 * 0.7+0.1 * 0.7+0.1 * 0.7+0.04 * 0.6 \\
& +0.05 * 0.6) \\
= & 0.5895
\end{aligned}
$$

$$
\begin{aligned}
\mathrm{OWAP}_{2}= & (0.05 * 1+0.25 * 1+0.3 * 1+0.05 * 0.9+0.01 * 0.9 \\
& +0.05 * 0.9+0.1 * 0.9+0.1 * 0.9+0.04 * 0.9 \\
& +0.05 * 0.8) \\
= & 0.955
\end{aligned}
$$

$$
\begin{aligned}
\mathrm{OWAP}_{3}= & (0.05 * 0.9+0.25 * 0.9+0.3 * .08+0.05 * 0.8 \\
& +0.01 * 0.8+0.05 * 0.8+0.1 * 0.8+0.1 * 0.8 \\
& +0.04 * 0.8+0.05 * 0.7) \\
= & 0.825
\end{aligned}
$$

In this situation, also it select the $P_{2}$ proposal as the choice with the highest coefficient.

Table 11 presents a comparison between the three algorithms

Table 8

Vector of weights determined (Own source, 2017). 
Table 9

Reordering the data (Own source, 2017).

\begin{tabular}{lllllllllll}
\hline & $C_{1}$ & $C_{2}$ & $C_{3}$ & $C_{4}$ & $C_{5}$ & $C_{6}$ & $C_{7}$ & $C_{8}$ & $C_{9}$ & $C_{10}$ \\
\hline$P_{1}$ & 1 & 0.09 & 0.8 & 0.8 & 0.8 & 0.7 & 0.7 & 0.7 & 0.6 & 0.6 \\
$P_{2}$ & 1 & 1 & 1 & 0.9 & 0.9 & 0.9 & 0.9 & 0.9 & 0.9 & 0.8 \\
$P_{3}$ & 0.9 & 0.9 & 0.8 & 0.8 & 0.8 & 0.8 & 0.8 & 0.8 & 0.8 & 0.7
\end{tabular}

Table 10

The OWA Results (Own source, 2017).

\begin{tabular}{ll}
\hline$O W A P_{1}$ & 0.590 \\
$O W A P_{2}$ & 0.955 \\
$O W A P_{3}$ & 0.825 \\
\hline
\end{tabular}

Table 11

The final results (Own source, 2017).

\begin{tabular}{|c|c|c|c|}
\hline \multirow[t]{2}{*}{ Proposals } & \multicolumn{3}{|c|}{ Algorithms/Selection Criteria } \\
\hline & $\begin{array}{l}\text { Hamming } \\
\text { Distance (Shortest } \\
\text { distance) }\end{array}$ & $\begin{array}{l}\text { Adequacy Ratio } \\
\text { (Highest adequacy } \\
\text { ratio) }\end{array}$ & $\begin{array}{l}\text { OWA Operators } \\
\text { (Highest } \\
\text { coefficient) }\end{array}$ \\
\hline$P_{1}$ Subway & 0.0187 & 0.29 & 0.5895 \\
\hline $\begin{array}{l}P_{2} \text { The Aeromovel } \\
\text { System }\end{array}$ & 0.0065 & 1 & 0.955 \\
\hline $\begin{array}{l}P_{3} \text { Tramway and } \\
\text { Light Rail Transit } \\
\text { (LRT) }\end{array}$ & 0.0086 & 0.3 & 0.825 \\
\hline
\end{tabular}

that were used in the simulation and the selection criteria. The results found indicate that the proposal $\left(P_{2}\right)$, the Aeromovel System, obtained the best result compared with the others and in all algorithms used.

The main reasons for this result has been the good evaluation of the proposal $\left(P_{2}\right)$ obtained in the specific characteristic of Energy consumption $\left(C_{2}\right)$, Environment and Sustainability $\left(C_{3}\right)$, Investments $\left(C_{7}\right)$ and Incorporation to the urban location $\left(C_{8}\right)$. These criteria received a greater weight from the government and industry experts.

The solution represents a consensus among the stakeholders on the approach that has been initially given in the field of sustainable transport. Subsequently, the public agent will be able to benefit from this tool in the decision making on this topic.

The described procedure allows flexibility in the implementation of algorithms because, under the circumstances, valuations and criteria, the results may vary. However, when the three results do not coincide on the same proposal, the uncertainty becomes so great that there is no convergence towards a single proposal. In this case, the public agent must make your decision by analysing all of the results and urgencies, selecting the proposal that is most beneficial to sustainability and the balance of forces operating in the public interest.

The Fuzzy Logic models have shown to be useful for analysing complex systems, such as the stakeholder dialogue and issues related to sustainable development. For these reasons, the results allow a deep thinking and a use to the academic and professional fields.

\section{Conclusions}

We propose a reflection on transportation problems in many cities of the world and expand the discussion on climate change and solutions to reduce the impacts caused by humanity. Following are the key findings of this paper:

First, Aeromovel System was presented as a sustainable alternative for the transport sector.

Second, the results of the bibliometric study identified the research gaps using algorithms of the fuzzy logic applied to sustainability. There is an opportunity to explore innovative research in this area.

Third, we use three algorithms that can support decisionmaking, getting qualitative data from a discussion with stakeholders. It is an innovative and useful tool for the process of proposal selection that can be applied in governmental institutions.

Fourth, as a result of a model implementation the Aeromovel System was elected among other means of transport like subway, tramway and light rail transit. Our findings suggest that modal has been the best alternative and symbolizes a consensus among stakeholders on the orientation previously adopted by the public agent on the subject of sustainable transport.

Fifth, the Fuzzy Logic models can contribute to a sustainable environment helping governments to decide for a better modal of transportation for the cities, and consequently reduce the $\mathrm{CO}_{2}$ emissions and increase the companies' productivity.

Sixth, the document identifies the importance of the participation of stakeholder, reinforces legitimacy and transparency in decision-making processes.

Finally, we consider that this article and its results may support future study on sustainability in general, and especially in the transport sector.

Stakeholder management is increasingly important towards sustainability. Therefore, future research work may also study the processes of identification, segmentation and prioritization and dialogue with stakeholders. Likewise, the possibilities for advancing research in the scientific knowledge of decision theory and in the studies on the application of fuzzy methodology in stakeholder management are confirmed.

\section{Acknowledgments}

The authors thank to CENTRUM Catholica, São Paulo Research Foundation (Fapesp Process No. 2015/24560-0) and National Council for Scientific and Technological Development (CNPq Process No. 306214/2015-6).

\section{References}

Alford, J., O'Flynn, J., 2009. Making sense of public value: concepts, critiques and emergent meanings. Int. J. Public Adm. 32 (3-4), 171-191.

Álvarez, C., 2017. Autonomous Authority of Urban Transport, CENTRUM Al Día. In Spanish (Accessed 15 June 2017). http://centrumaldia.com/60-Cesar_Alvarez/ 4051-Autoridad_Autonoma_de_Transporte_Urbano\#.WURWa2iGMdU.

Amini, M.H., Islam, A., 2014. Allocation of electric vehicles' parking lots in distribution network. Innovative smart grid technologies conference (ISGT). IEEE PES 1-5. https://doi.org/10.1109/ISGT.2014.6816429.

Andriantiatsaholiniaina, L.A., Kouikoglou, V.S., Phillis, Y.A., 2004. Evaluating strategies for sustainable development: fuzzy logic reasoning and sensitivity $\begin{array}{lllll}\text { analysis. Ecol. Econ. } 48 \text { (2), 149-172. https://doi.org/10.1016/ } & \end{array}$ j.ecolecon.2003.08.009.

Babalik-Sutcliffe, E., 2002. Urban rail systems: analysis of the factors behind success. Transp. Rev. 22 (4), 415-447.

Baumgartner, R.J., Rauter, R., 2017. Strategic perspectives of corporate sustainability management to develop a sustainable organization. J. Clean. Prod. 140 (Part 1), 81-92. https://doi.org/10.1016/j.jclepro.2016.04.146.

Bertrand, J.W.M., Fransoo, J.C., 2002. Int. J. Operat. Prod. Manag. 22 (2), 241-264. https://doi.org/10.1108/01443570210414338.

Blanco-Mesa, F., Merigó Lindahl, J.M., Gil-Lafuente, A.M., 2016. A bibliometric analysis of fuzzy decision making research. In: Annual Conference of the North American Fuzzy Information Processing Society (NAFIPS). IEEE, pp. 1-4. https:// doi.org/10.1109/NAFIPS.2016.7851585. El Paso, TX, USA.

Bozeman, B., 2007. Public Values and Public Interest: Counterbalancing Economic Individualism. Georgetown University Press, Washington, DC.

Bozeman, B., 2009. Public values theory: three big questions. Int. J. Public Policy 4 (5), 369-375.

Broman, G.I., Robèrt, K.-H., 2017. A framework for strategic sustainable development. J. Clean. Prod. 140, 17-31. https://doi.org/10.1016/j.jclepro.2015.10.121.

Brons, M., Givoni, M., Rietveld, P., 2009. To railway stations and its potential in 
increasing rail use. Transp. Res. Part A 43, 136-149.

Coester, M., 2017. http://www.aeromovel.com.br/en/(Accessed 10.06.17).

Ferbrache, F., Knowles, R.D., 2017. City boosterism and place-making with light rail transit: a critical review of light rail impacts on city image and quality. Geoforum 80, 103-113.

França, C.L., Broman, G., Robèrt, K.-H., Basile, G., Trygg, L., 2017. An approach to business model innovation and design for strategic sustainable development J. Clean. Prod. 140 (Part 1), 155-166. https://doi.org/10.1016/ j.jclepro.2016.06.124.

Gil Aluja, J., 1999. Elements for a Theory of Decision in Uncertainty. Kluwer Academic Publishers Dordrech, Boston. London, pp. 125-140.

Gil-Lafuente, A.M., 2001. New Strategies for Financial Analysis in the Company ( In Spanish. Ariel Editorial. Barcelona).

Gil-Lafuente, A.M., Paula, L.B., 2013. Algorithm applied in the identification of stakeholders. Kybernetes 42 (5), 674-685. https://doi.org/10.1108/K-04-20130073.

Griffin, T., 2002. Shared track - a new dawn? Proceedings institution of mechanical engineers - Part F. J. Rail Rapid Transit 216, 15-22.

Hass-Klau, C., Crampton, G.R., Benjari, R., 2004. Economic Impacts of Light Rail: the Results for 15 Urban Areas in France, Germany, UK and North America. Environmental and Transport Planning, Brighton, UK.

Hensher, D., 2007. Delivering value for money to government through efficient and effective public transit service continuity: some thoughts. Transp. Rev. 27 (4), $411-448$.

Hodgson, P., Potter, S., Warren, J., Gillingwater, D., 2013. Can bus really be the new tram? Res. Transp. Econ. 39 (1), 158-166.

Humphries, H.C., Bourgeron, P.S., Reynolds, K.M., 2008. Suitability for conservation as a criterion in regional conservation network selection. Biodivers. Conservat. 17 (Issue 3), 467-492. https://doi.org/10.1007/s10531-007-9245-8.

Ison, S., Rye, T., 2005. Implementing road user charging: the lessons learnt from Hong Kong, Cambridge and Central London. Transp. Rev. 25 (4), 451-465.

Kaufmann, A., 1973. Introduction to the Theory of Fuzzy Subsets. In French. Vol. 1 Ed. Masson. Paris.

Kaufmann, A., Gil Aluja, J., 1987. Operational Management Techniques for the Treatment of Uncertainty. Editorial Hispano Europa. Barcelona, pp. 20-56 (In Spanish).

Kennedy, C., Miller, E., Shalaby, A., Maclean, H., Coleman, J., 2005. The four pillars of sustainable urban transportation. Transp. Rev. 25 (4), 393-414. https://doi.org/ 10.1080/01441640500115835.

Knowles, R.D., 1992. Light rail transport. In: Whitelegg, J. (Ed.), Traffic Congestion: Is There a Way Out? Leading Edge Press, Hawes, pp. 107-133.

Kouloumpis, V.D., Kouikoglou, V.S., Phillis, Y.A., 2008. Sustainability assessment of nations and related decision making using fuzzy logic. IEEE Syst. J. 2 (2) 224-236. https://doi.org/10.1109/JSYST.2008.925256.

Lin, B., Omojub, O.E., 2017. Does private investment in the transport sector mitigate the environmental impact of urbanisation? Evid. Asia J. Clean. Prod. 153, 331-341. https://doi.org/10.1016/j.jclepro.2017.01.064.

Mackett, R.I., Edwards, M., 1998. The impact of new urban public transport systems: will the expectations be met? Transp. Res. A 32 (4), 231-245.

Mintrom, M., Luetjens, J., 2017. Creating public value: tightening connections between policy design and public management. Policy Stud. J. 45, 170-190.

Missimer, M., Robèrt, K.-H., Broman, G., 2017. A strategic approach to social sustainability - Part 1: exploring the social system. J. Clean. Prod. 140, 32-41. https://doi.org/10.1016/j.jclepro.2016.03.170.

Moore, M.H., 1995. Creating Public Value: Strategic Management in Government. Harvard University Press, Cambridge, MA

Moore, M.H., 2013. Recognizing Public Value. Harvard University Press, Cambridge, MA.

Moulton, S., 2009. Putting together the publicness puzzle: a framework for realized publicness. Public Adm. Rev. 69 (5), 889-900.

National Geographic, 2010. http://www.nationalgeographic.es/medio-ambiente/seha-parado-el-calentamiento-global (Accessed 19.06.17)

Nie, S., Huang, C.Z., Huang, G.H., Li, Y.P., Chen, J.P., Fan, Y.R., Cheng, G.H., 2016 Planning renewable energy in electric power system for sustainable development under uncertainty - a case study of Beijing. Appl. Energy 162, 772-786. https://doi.org/10.1016/j.apenergy.2015.10.158.

Novales, M., Orro, A., Bugarin, M.R., 2002. The tram-train: state of the art
Proceedings Institution of Mechanical Engineers. Part F J. Rail Rapid Transit 216, $1-13$

Novales, M., Orro, A., Bugarin, M.R., 2003. Madrid tram-train feasibility study conclusions. Proceedings Institution of Mechanical Engineers. Part F J. Rail Rapid Transit 217 (1), 1-10. https://doi.org/10.1177/095440970321700101.

Paula, L.B., 2011. Management Models Applied to Business Sustainability. Doctoral Thesis. University of Barcelona. In Spanish. http://hdl.handle.net/10803/32219 (Accessed 10 July 2017).

Pedrycz, W., 1994. Why triangular membership functions. Fuzzy Sets Syst. 64 (1), 21-30.

Prato, T., 2005. A fuzzy logic approach for evaluating ecosystem sustainability. Ecol. Model. 187 (2-3), 361-368. https://doi.org/10.1016/j.ecolmodel.2005.01.035.

Prato, T., 2008. Stochastic multiple attribute evaluation of land use policies. Ecol. Model. 219 (1-2), 115-124. https://doi.org/10.1016/j.ecolmodel.2008.08.006.

Pucher, J., Peng, Z., Mittal, N., Zhu, Y., Korattyswaroopam, N., 2007. Urban transport trends and policies in China and India: impacts of rapid economic growth. Transp. Rev. 27 (4), 379-410.

Rauter, R., Jonker, J., Baumgartner, R.J., 2017. Going one's own way: drivers in developing business models for Sustainability. J. Clean. Prod. 140, 144-154. https://doi.org/10.1016/j.jclepro.2015.04.104.

Reynolds, K.M., Johnson, K.N., Gordon, S.N., 2003. The science/policy interface in logic-based evaluation of forest ecosystem sustainability. For. Policy Econ. 5 (4), 433-446. https://doi.org/10.1016/S1389-9341(03)00041-8.

Robèrt, M., 2017. Engaging private actors in transport planning to achieve future emission targets e upscaling the Climate and Economic Research in Organisations (CERO) process to regional perspectives. J. Clean. Prod. 140, 324-332. https://doi.org/10.1016/j.jclepro.2015.05.025.

Schrank, D., T, et al., 2015. TTIs 2015 urban mobility Report. Tex. Transp. Inst.

Su, W.C., Rahimi-Eichi, H., Zeng, W.T., Chow, M.Y., 2012. A Survey on the electrification of transportation in a smart grid environment. IEEE Trans. Ind. Inf. 8 (1), 1-10. https://doi.org/10.1109/TII.2011.2172454.

Talbot, C., 2009. Public value - the next 'big thing' in public management? Int. J. Public Adm. 32 (3-4), 167-170.

Thanh, V.H., Roberts, C, Tobias, A.M., Williams, J., Stirling, A. Madelin, K., 2008. Decision support at the wheel-rail interface: the development of system functional requirements. Proceedings Institution of Mechanical Engineers - Part F. J. Rail Rapid Transit 222, 195-206.

Topp, H.H., 1998. Renaissance of trams in Germany - five case studies. Proceedings Institution of Mechanical Engineers - Part F. J. Rail Rapid Transit 212, 227-233.

United Nations Framework Convention on Climate Change (UNFCCC), 2017. Conference of the Parties (COP22). http://cop22.ma/en/\#actualites/withdrawal-ofthe-united-states-from-the-paris-agreement-a-profound-disappointment (Accessed 20 June 2017).

Vasic, B., Popovic, V., Vuchic, V.R., Danon, G., Vencl, A., 2012. Defining the functiona and physical compatibility of a modernized tramway rolling stock with a newly planned LRT system: a case study of Belgrade. Transp. Plan. Technol. 35 (3), 241-261. https://doi.org/10.1080/03081060.2012.671019.

Vianna, G.S.B., Machado, D.C., 2016. An analysis of the costs of urban mobility in Brazil. In: Proceedings of XXX National Association of Research and Teaching in Transportation (ANPET) Rio de Janeiro, Brazil. In Portuguese. http://www.anpet. org.br/xxxanpet/site/anais_busca_online/documents/4_563_AC.pdf (Accessed 19 June 2017)

Vuchic, V.R., 2005. Urban Transit Operations - Planning and Economics. John Wiley \& Sons, Hoboken, NJ.

Vuchic, V.R., 2007. Urban Transit - Systems and Technology. John Wiley \& Sons, Hoboken, NJ.

Vuchic, V.R., 2008. Transport systems and policies for sustainable cities. Therm. Sci. 12 (4), 7-17.

World Commission on Environment and Development (WCED), 1987. Our Common Future. http://www.un-documents.net/ocf-ov.htm\#I.3 (Accessed 20 June 2017). Yager, R.R., 1993. Families of OWA operators. Fuzzy Sets Syst. 59 (2), 125-148.

Yager, R.R., 1998. On ordered weighted averaging aggregation operators in multicriteria decision making. IEEE transactions on systems. Man Cybern. 18, 183-190.

Zadeh, L.A., 1965. Fuzzy sets. Inf. Control J. 8 (3), 338-353. https://doi.org/10.1016/ S0019-9958(65)90241-X. 